\title{
Affirming Verb Lexemes in A Practical Ndebele Dictionary and in Isichazamazwi SesiNdebele: The Case of -wa Verbs
}

Jerry Zondo, Department of African Languages and Literature, University of Zimbabwe, Harare, Zimbabwe (jerryzondo@arts.uz.ac.zw)

\begin{abstract}
Both A Practical Ndebele Dictionary (1971) by Pelling and Isichazamazwi SesiNdebele (2001) by Hadebe et al. lemmatize a number of -wa-ending verbs. Each one of the verbs is easily recognizable as a canonical or base form from which different word forms can be derived. Indeed they should all be seen as legitimate headwords that have been carefully selected for entry until a keener observation as presented in this article, questions the validity of the inclusion. It would be understood from both compilers that all the verbs entered are by virtue of their being legitimate verb bases. Since the verbs ending with -wa are canonical forms, they should be inflected with -iw-/-w-, the passive extension morpheme, and by any other extension morphemes. When -iw-/ -w- cannot inflect directly, the usual initial inflection to causative or applicative and then to passive should then apply. When -iw-/-w- cannot apply, it is likely that the headword in question is in fact a passive form already derived from another base form. The article argues that these words cannot claim to be legitimate headwords. The article further observes that other verb endings treated can be similarly tested and treated accordingly. Possibly headword selection will then be more consistent and characterized by a more considered and reasoned approach.
\end{abstract}

Keywords: BASE FORM, CANONICAL FORM, DICTIONARY ENTRY, DERIVATION, HEADWORD, INFLECTION, PREDICTABILITY, SELECTION, STYLIZED VERBAL EXTENSION

Opsomming: Die bevestiging van werkwoordlekseme in A Practical Ndebele Dictionary en in Isichazamazwi SesiNdebele: Die geval van -wa-werkwoorde. Sowel A Practical Ndebele Dictionary (1971) deur Pelling en Isichazamazwi SesiNdebele (2001) deur Hadebe et al. lemmatiseer 'n aantal -wa-eindigende werkwoorde. Elkeen van die werkwoorde is maklik herkenbaar as 'n kanonieke of basisvorm waarvan verskillende woordvorme afgelei kan word. Hulle moet inderdaad almal gesien word as egte trefwoorde wat noukeurig gekies is vir opname totdat ' $n$ skerper beskouing soos aangebied in hierdie artikel die geldigheid van insluiting bevraagteken. Dit word deur altwee samestellers te kenne gegee dat al die werkwoorde opgeneem is op grond daarvan dat hulle egte werkwoordbasisse is. Aangesien werkwoorde wat op -wa eindig kanonieke vorme is, behoort hulle verbuig te word met -iw-/-w-, die passiewe uitbreidingsmorfeem, en deur enige ander uitbreidingsmorfeme. Wanneer -iw-/-w- nie direk kan verbuig nie, behoort die gewone beginverbuiging na kousatief of applikatief en dan na passief van toepassing te wees. Wanneer -iw-/-w- nie van toepassing kan wees nie, is dit waar- 
skynlik dat die betrokke trefwoord in werklikheid ' $n$ passiewe vorm is wat alreeds afgelei is van ' $n$ ander basisvorm. Die artikel redeneer dat hierdie woorde nie aanspraak kan maak om egte trefwoorde te wees nie. Die artikel merk verder op dat ander werkwoorduitgange op dieselfde manier getoets en dienooreenkomstig behandel kan word. Moontlik sal die keuse van werkwoorde dan meer konsekwent wees en deur 'n meer deurdagte en beredeneerde benadering gekenmerk word.

Sleutelwoorde: BASISVORM, KANONIEKE VORM, WOORDEBOEKINSKRYWING, AFLEIDING, TREFWOORD, VERBUIGING, VOORSPELBAARHEID, KEURING, GESTILEERDE VERBALE UITBREIDING

\section{Introduction}

Two dictionaries in Ndebele that are widely used by students from secondary to university education and by teachers and lecturers in various institutions have been compiled by Pelling (1971) and Hadebe et al. (2001). Pelling's work is appropriately called A Practical Ndebele Dictionary (forthwith PND), because it is a bilingual dictionary most usable in practical situations of translation, especially by first and second year secondary students and by practitioners in language service institutions writing and translating tracts into Ndebele-English, English-Ndebele. The second dictionary with Hadebe as chief editor is called Isichazamazwi SesiNdebele (forthwith ISN), the first monolingual dictionary published in Ndebele meant for high school, college and university students. The Ndebele section of the African Languages Research Institute (ALRI) at the University of Zimbabwe, Harare, is planning an advanced Ndebele dictionary whose compilation will gain from reactions to and analyses of the PND and the ISN. The following article aims to make a contribution toward headword selection of verbs, attempting to be representative of any type of dictionary. It refers to the appropriateness of an entry, its legitimacy and the linguistic justification for its choice. The compilation of an advanced Ndebele dictionary will indeed be a more complex but more geared activity central around considered and reasoned approaches to dictionary making.

The selection of headwords for any dictionary is a key stage in dictionary compilation. It impacts on the user-friendliness of a dictionary and on its suitability to its various target users. Each lexicographer has her own considerations on selection but a target user will sometimes seek the selection criteria for certain canonical forms that a lexicographer has worked with in order to make sense of the dictionary under consideration. A more consistent and informed selection system is likely to appeal and be quite usable to the target user (cf. Chabata 1998: 141). This article seeks to make a contribution toward a scientific selection of entries for future dictionary work in Ndebele by making certain presumptions on the selection criteria for the PND and ISN. There is another Ndebele dictionary, Isichazamazwi SezoMculo that, because of its specialization in music terminology in Ndebele, does not apply to this investigation. 
This article looks at the -wa-ending verbs in the PND and the ISN to establish if the two dictionaries have been consistent and accurate in using an appropriate canonical set in all cases. The principles of selection the lexicographers used are considered and evaluated. The aim is to establish a legitimate -wa verb entry and consequently, legitimate entries for all the other verbs which might be confused with a verb extension inflection. An overriding criterion is that a legitimate -wa entry should be inflected by -iw-/-w-, a passive morpheme, to be a valid base form. If it cannot, then it would already be a passive form of an appropriate original base form and should be excluded from the headword list. Furthermore, the -wa-ending verb canonical forms should be freely inflected by other stylized extension morphemes.

Since the PND and the ISN are used in schools, colleges and universities, the basic assumption is that all the users have a sufficient knowledge and training to easily predict, or to predict with some consideration, the necessary and appropriate inflections and derivations of new words from the given base forms (cf. Chabata 1998: 142-143). The same users can easily do the same with -wa-ending verbs as bases. The research however reveals that compilers of both dictionaries have included forms that should be eliminated. Main entry selection depends on space, size, the frequency of the usage of a term, the specialization of the dictionary, a comprehensive and balanced coverage, the appropriateness of the vocabulary to the target group, legitimate entries or entry lexical validity, and a sense of what is wanted (Landau 2001: 356-359).

\section{2. -wa verb forms in PND and ISN}

Pelling has 14 entries of -wa verbs. The entire PND has 154 pages including the front and back matter, but the dictionary does not state the actual number of entries. Hadebe has 37 -wa verb entries in the ISN. Hadebe (2001: xxxiv) declares "zilutshwane impambosi zesenzo ezethuliweyo lapha" (there are only a few verb extension forms that have been entered here (as headwords)).The entire ISN has 556 pages including back matter. The ISN has 47 pages of front matter. The ISN fittingly has more information on how the dictionary has been compiled and is to be used. It provides more details on Ndebele grammar than does PND.

Pelling's entries are the following:

dakwa, v.i.: be drunk; ehlelwa, v.i.: experience; felwa, v.i.: be bereaved of; fuywa, v.i.: 1, be addicted to, 2, be domesticated; gwegwa, v.t.: hook, catch on a hook; helelwa, v.i. be in labour, have labour pains; hlulukelwa, v.i.: be sad; khohlwa, v.t.: forget; kholwa, v.t.: believe, trust, have faith; khulelwa, v.i.: become pregnant; lwa, v.t.: fight, contend; selwa, v.i.: 1, wane (of moon); 2, be late; wa, v.i.: fall, drop down; zwa, v.t.: 1 , hear, understand; 2 , feel; 3 , taste. 
The 37 entries of Hadebe are as follows:

aziwa (get known), banjwa (get caught), bekwa (get placed at), bhajwa (get stuck), bulawa (get killed), buthwa (get collected), dakwa (get drunk), dinwa (get tired), dletshwa (get scratched), dliwa (get eaten), ehlelwa (experience), felwa (have death in the family), fuywa (get addicted to), gwegwa (hook), gqwagqwa (get cooked), gqwegqwa (skirt an area), helelwa (feel birth pains), hlelwa (get organized), hitshwa (get choked), hlulukelwa (be sad), hlwa (turn to dusk), jutshwa (get impaled), khohlwa (forget), kholwa (believe), khulelwa (be overpowered), lwa (fight), nethwa (be drenched), phiswa (be pressed by urine), qalekiswa (be condemned by the divine), selwa (wane), sikiswa (accept a meat dish (be a bride for the first time)), thwithwa (drink noisily), tshonelwa (be delayed into evening), vukelwa (get possessed by an evil spirit), vuthwa (ripen), zalelwa (be born at), zikhohlwa (be extremely drunk).

The translations will in some cases lean towards the passive form. Pelling provides his own translations. As Hadebe's ISN is a monolingual dictionary, the glossing is by the author of this article.

\section{Proof of the base form status}

The selection criterion for most dictionary entries starts with a base form. A base "refers to any part of the word seen as a unit to which an operation can be applied, as when one adds an affix to a root or stem" (Crystal 1991: 35). The base form is sometimes called the lexeme, "the abstract unit which underlies some of the variants ... observed in connection with words" (Carter 1998: 7). The lexemes will underlie different grammatical variants which Carter (1998) calls word-forms. Lexemes will then be the basic contrasting units of vocabulary. Dictionaries enter lexemes rather than words. Words become predictable to language users who will, with assistance from sound linguistic training, derive the necessary words as and when needed in varied contexts. Invariably according to the general language, Pelling (1979: 19) will enter -DAKWA as a lexeme, and if he has provided sufficient front matter on verb extensions and the principle of inflection and derivation, the dictionary user will predict the word-forms dakwela (get drunk at/for); dakwiswa (be made drunk by); dakwisisa (be really drunk); in all cases of inflection, the root -dakw- is retained, and might appear at a glance to be adequate proof of the base form status of dakwa, but Pelling has a wrong base form here; the right one is -dakwith dakela, dakiswa and dakisisa as derived forms. Pelling's lexeme should be -DAKA. Hadebe (2001: 315) will enter -LWA as a lexeme but the user can once again derive its word-forms independently as lwela (fight for); lwisa (cause to fight), lwiwa (fought by); lweka (can be fought); lwisisa (fight extremely well); zilwela (fight for oneself). Luckily for both lexicographers, the two lexemes derive several word-forms each; each lexeme is therefore an ap- 
propriate base, a canonical form and therefore a suitable headword to choose for a general language entry. While the second is a good example of a -waending verb, the first is not.

When -wa-ending verbs take on the stylized verb extension -iw-/-w-, the choice of this base form becomes even more easily and more compelling to the linguist. No further proof would then be needed to establish the status of the base form. The following verbs taken from both Pelling and Hadebe are inflected by the passive extension morpheme:

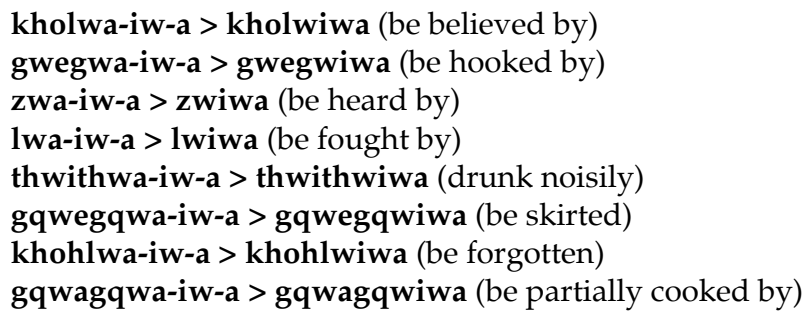

The status of the set of verbs in the above examples as base forms leaves little doubt.

Many verbs in Ndebele will not inflect directly into the passive form. The passive inflection is then realized through another verb extension morpheme. The causative form easily takes the initial inflection on behalf of the passive. The following verbs illustrate this process:

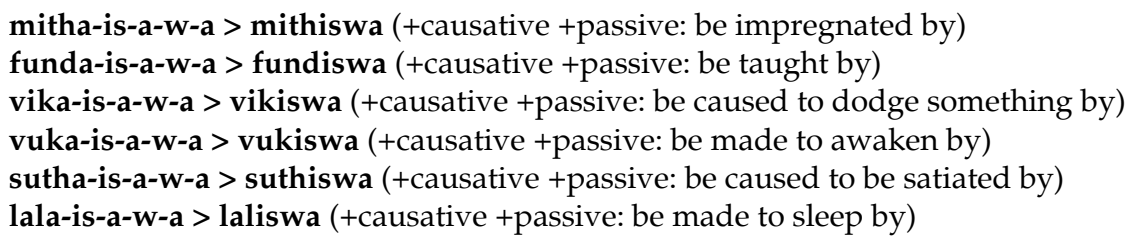

It is likely that the six relevant verbs indicate a state, a process, or a condition. Their passivization will not be direct but will depend on an initial causative formation. A set of -wa verbs from PND and ISN behave in a similar manner to the six verbs above. The following verbs from Pelling and Hadebe illustrate the point:

bulawa-is-a-w-a > bulawiswa (+causative + passive: be caused to die by) dakwa-is-a-w-a > dakiswa (be caused to be drunk by)

helelwa-is-a-w-a > helelwiswa (+causative +passive: caused to feel birth pains by)

hlulukelwa-is-a-w-a > hlulukelwiswa (+causative + passive: be saddened by)

hlwa-is-a-w-a > hlwiswa (+causative + passive: caused to be dark by)

phiswa-is-a-w-a > phiswiswa (+causative + passive: caused to be pressed by)

selwa-is-a-w-a > selwiswa (+causative + passive: caused to be late by)

vuthwa-is-a-w-a > vuthwiswa (+causative + passive: caused to ripen by) 
The direct inflection by -iw-/-w- of eight of these -wa verbs affirms and confirms their categorical status as base forms. They have appropriately been selected as headwords for both dictionaries.

Khumalo (2007) refers to all verbs forming the basis for the discussion in this article as deponent verbs. He states that they are passive in form, but active in meaning. There are very few of these verbs in Ndeble. The two following are given by Canonici (1996):

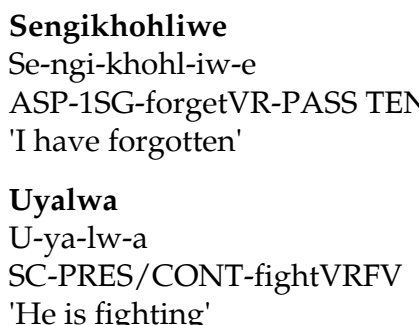

Khumalo further points out some verbs in Ndebele that are used more extensively in the passive than in the active form. They will appear in dictionaries as appropriately lemmatized, not being so problematic as -wa-ending verbs. In fact, Khumalo (2007: 105-113) presents a summary of all verbal derivations which will be useful for future dictionary making. His examples and annotations cannot be ignored by any dictionary maker.

\section{4. -wa forms that are not really base}

The PND and the ISN have -wa verbs that actually do not belong to this category. The verbs can be eliminated by the test described in Section 3. It is easy to determine their derivation, making it unnecessary to enter them as base forms. They can then be considered as word forms from other appropriate bases. From Pelling's initial list of 14 verbs, three can easily be eliminated as word and not as base forms, using the following evidence:

dinwa $<$ dina-w-a: inflection of base form -din- (tire)

ehlelwa < ehlela-w-a: inflection of base form -ehlel- (experience)

fuywa < fuya-w-a: inflection of base form -fuy- (rear)

Pelling will be left with only 11 genuine -wa ending verbs.

Hadebe with 37 entries can have his reduced to only 16. The following 21 of his verbs seem to fail the test:

aziwa < azi-w-a: inflection of base form -az- (know)

banjwa < bamba-w-a: inflection of base form -bamb- (hold, detain)

bekwa < beka-w-a: inflection of base form -bek- (place)

bhajwa < bhaja-w-a: inflection of base form -bhaj- (stuck)

buthwa < butha-w-a: inflection of base form -buth- (collect) 


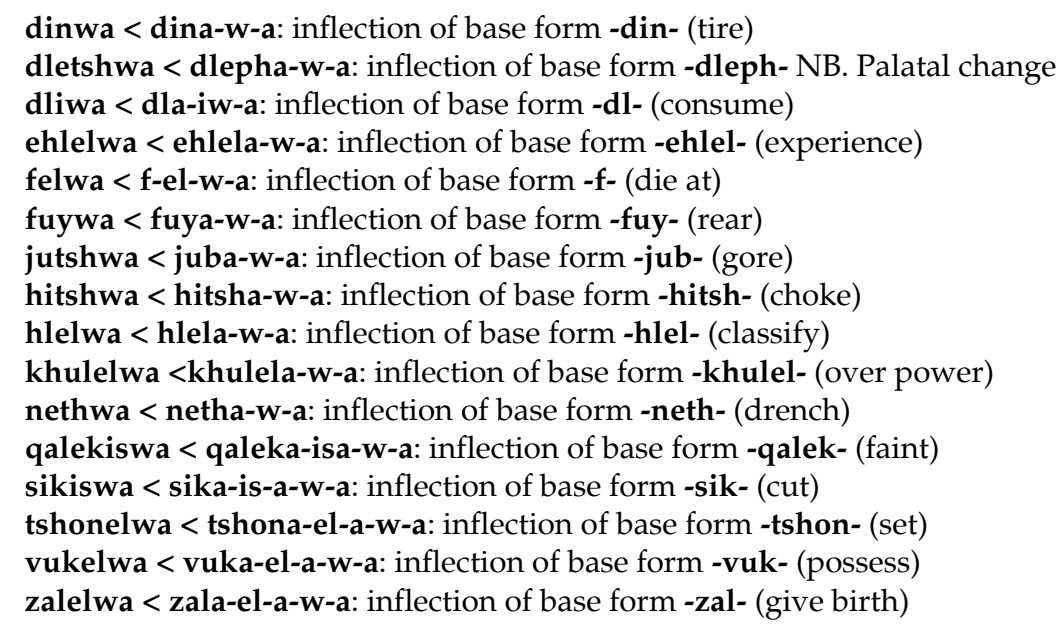

Only 16 genuine -wa verbs will remain for Hadebe, five more than those for Pelling. If all base forms shown as inflected here would have already been entered as headwords by Hadebe, then it would be unnecessary to add their passivized forms as entries.

It is clear that a thorough search in Ndebele for -wa-ending verbs will not yield more than about 25 in the entire language.

\section{The redundancy rule in lexicography}

There must be the use of the redundancy rule in lexicography that will direct headword selection. Obviously the stylized verb extension word forms would be redundant when dictionary users already know the principles of derivation. The verb headword will indicate the selection that the radical will make of extension forms after which the users will form the necessary inflections on their own. The strength of the lexicographic entry will be to show the selection as accurately as possible. Just as all plural forms of nouns should not be entered when the singular forms have been lemmatized, so all the verb extension forms should not be entered as base forms. Only copulative and adverbial formatives should be lemmatized, the front matter explaining the use and derivation with general linguistics augmenting and confirming dictionary usage. The PND and the ISN have not fully exploited the redundancy rule with respect to stylized verb extensions.

\section{Standardization}

What will be considered as a standard entry for -wa-ending verbs will obviously be the main entry that can be inflected into various extension forms including -iw-/-w-. The process of standardization in the -wa verb forms will 
consist of consistently choosing as entries only such forms as can beyond doubt behave in the manner of the test established previously. Sager (1990: 115) calls, for example, for a standardization process that involves "the interest of economy ..., the interest of precision ..., the interest of appropriateness". The PND and the ISN show a limited application for each of the contentious verbs. Landau (2001: 357) calls for the selectivity principle, which has a telling effect on the size of any type of dictionary. When word lists for dictionaries are clearly spelt out and the principles of selection well laid out, then all entries in these dictionaries will be characterized by economy, precision and appropriateness. Subsequently, these dictionaries will adhere to the required standards. Hartmann (1983) indeed contends that "all dictionaries wittingly or unwittingly contribute to the codification of language use by their mere existence ..., seem to confer an uncontested authority upon those items listed". They can be undisputed authorities especially if an appropriate choice through adequate testing has been made. The main point is to ensure consistency by avoiding misinterpretations and then arriving at a uniform system of word selection. The standardization process will have an effect on future dictionaries if it is well employed in the compilation of the first or initial Ndebele dictionaries. The lexicographers will adhere firmly to the principles of an appropriate and scientific selection. Further, any present dictionary-making attempts for the Ndebele have inevitably to make a contribution toward the standardization of the Ndebele language in one way or another.

\section{Conclusion}

The PND and the ISN have entered -wa-ending verbs but have in the process confused -iw-/-w- inflections for -wa verbs. Subsequently the selection of base forms for -wa verbs has been affected, resulting in false entries. The basic contention is that a more consistent selection of verbs will ensure that only the appropriate base forms for the verbs in question are entered. If well selected, the base forms can be inflected by $-\mathbf{i w}-/-\mathbf{w}-$ as well as by the other appropriate stylized extension forms. When a verb is already in the passive form, it cannot be entered as a base form since the passive verb would already be provided for in the original base form. Because the expected scientific and linguistic choice system has not been fully followed, the PND and the ISN have lost out on space and on accuracy by extending the scope of the selection. Proof of base form status is necessary for the right choice of verbs for headword status. The lexicographer has to consider whether stylized extension forms are redundant when entered as base forms. Dictionary users can use the predictability principle in establishing all the possible forms that can be derived from a base form. An accurate selection of -wa verbs will indeed help dictionary users in arriving at the right verb types and at advancing their linguistic knowledge. Since dictionaries are essential tools for the codification of a language, due responsibility for accurate and tested selection becomes central in lexicography. It will then 
be easier for Ndebele dictionary users, and for language students in general, to pick out or select different types of verbs as base forms, especially if such verb forms end with syllables that might have been seen as stylized verb extensions. Ndebele dictionaries can then be used for several purposes including the effective standardization of the Ndebele language. Compilation of different types of dictionaries in Ndebele is bound to continue since only three Ndebele dictionaries are in use at present. Ndebeles frequently consult Zulu dictionaries and sometimes Xhosa dictionaries too. When further compilation of dictionaries continues, the compilers are likely to take a more positive consideration for the selection of entries which will possibly use a more concerted testing mechanism for the appropriate base forms. Further research is necessary on other verb endings that might on the surface be confused with the rest of the stylized verb radicals, such as -el-, the applicative form; -is-, the causative form; -isis-, the intensive form; -an-, the reciprocal form; and -ek- the neuter form. This means that there will be -ela-, -isa-, -isisa-, -ana-, -eka-ending verbs which should not be confused with any of the extensions discussed in this article.

\section{References}

Canonici, N.N. 1996. Zulu Grammatical Structure. Third Edition. Durban: University of Natal.

Carter, R. 1998. Vocabulary: Applied Linguistic Perspective. London: Allen and Unwin.

Chabata, E. 1998. Using the Predictability Criterion for Selecting Extended Verbs for Shona Dictionaries. Lexikos 8: 140-153.

Crystal, D. 1991. A Dictionary of Linguistics and Phonetics. Oxford: Basil Blackwell.

Hadebe, S. et al. (Eds.). 2001. Isichazamazwi SesiNdebele. Harare: College Press.

Hartmann, R.R.K. 1983. Lexicography: Principles and Practices. London: Academic Press.

Khumalo, L. 2007. An Analysis of the Ndebele Passive Construction. Unpublished Ph.D. Dissertation. Oslo: University of Oslo.

Landau, S.I. 2001. Dictionaries. The Art and Craft of Lexicography. Second Edition. Cambridge: Cambridge University Press.

Nkomo, D. and N. Moyo (Eds.). 2006. Isichazamazwi SezoMculo. Gweru: Mambo Press.

Pelling, J.N. 2001. A Practical Ndebele Dictionary. Second Edition. Harare: Longman Zimbabwe.

Sager, J.C. 1990. A Practical Course in Terminology Processing. Amsterdam: John Benjamins. 